Prepared for the U.S. Department of Energy

under Contract DE-AC05-76RL01830

\title{
Review of Natural Phenomena Hazard (NPH) Assessments for the DOE Hanford Site
}

\section{RL Snow \\ SB Ross}

September 2011

\section{Pacific Northwest}

NATIONAL LABORATORY 


\title{
DISCLAIMER
}

This report was prepared as an account of work sponsored by an agency of the United States Government. Neither the United States Government nor any agency thereof, nor Battelle Memorial Institute, nor any of their employees, makes any warranty, express or implied, or assumes any legal liability or responsibility for the accuracy, completeness, or usefulness of any information, apparatus, product, or process disclosed, or represents that its use would not infringe privately owned rights. Reference herein to any specific commercial product, process, or service by trade name, trademark, manufacturer, or otherwise does not necessarily constitute or imply its endorsement, recommendation, or favoring by the United States Government or any agency thereof, or Battelle Memorial Institute. The views and opinions of authors expressed herein do not necessarily state or reflect those of the United States Government or any agency thereof.

\author{
PACIFIC NORTHWEST NATIONAL LABORATORY \\ operated by \\ BATTELLE \\ for the \\ UNITED STATES DEPARTMENT OF ENERGY \\ under Contract DE-AC05-76RL01830 \\ Printed in the United States of America \\ Available to DOE and DOE contractors from the \\ Office of Scientific and Technical Information, \\ P.O. Box 62, Oak Ridge, TN 37831-0062; \\ ph: (865) 576-8401 \\ fax: $(865) 576-5728$ \\ email: reports@adonis.osti.gov

\begin{abstract}
Available to the public from the National Technical Information Service, U.S. Department of Commerce, 5285 Port Royal Rd., Springfield, VA 22161 ph: (800) 553-6847 fax: (703) 605-6900 email: orders@ntis.fedworld.gov online ordering: http://www.ntis.gov/ordering.htm
\end{abstract}

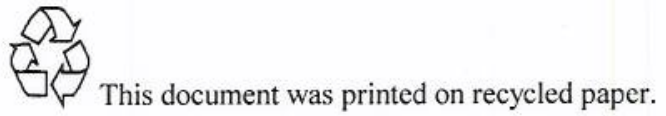




\section{Review of Natural Phenomena Hazard (NPH) Assessments for the DOE Hanford Site}

RL Snow

SB Ross

September 2011

Prepared for the U.S. Department of Energy under Contract DE-AC05-76RL01830

Pacific Northwest National Laboratory

Richland, Washington 99352 


\section{Executive Summary}

The purpose of this review is to assess the need for updating Natural Phenomena Hazard (NPH) assessments for the DOE's Hanford Site, as required by DOE Order 420.1B Chapter IV, Natural Phenomena Hazards Mitigation, based on significant changes in state-of-the-art NPH assessment methodology or site-specific information. This review is an update and expansion to the September 2010 review of PNNL-19751, Review of Natural Phenomena Hazard (NPH) Assessments for the Hanford 200 Areas (Non-Seismic).

In this context, it was determined that seismic and volcanic hazard assessments require updating. The wind hazard assessment will require updating once changes to methodology published in ASCE/SEI 7-10 are adopted into the International Building Code, and update is recommended in anticipation of that adoption. Other existing NPH assessments, as described in WHC-SD-GNER-501, Natural Phenomena Hazards, Hanford Site, Washington, are consistent with or bounded by current design methodology and site specific data.

Hazard Assessment and design criteria revision is also appropriate for other natural phenomena hazards not currently included in the scope of WHC-SD-GN-ER-501 to update design standards or provide explicit discussion of non-applicability in response to DOE G 420.1-2 Appendix C listing. 


\section{Contents}

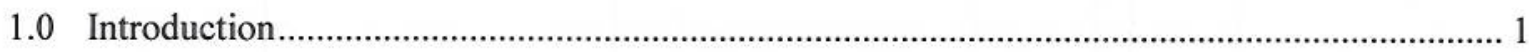

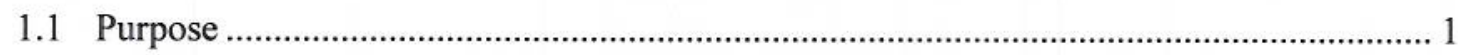

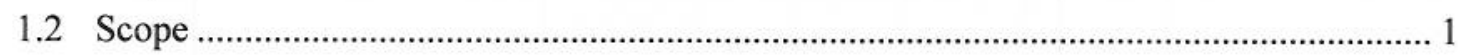

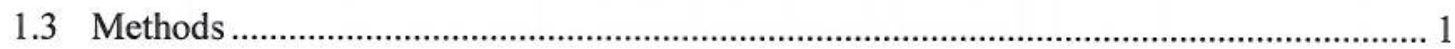

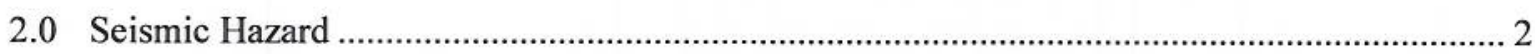

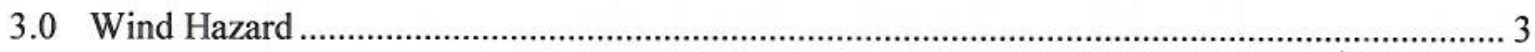

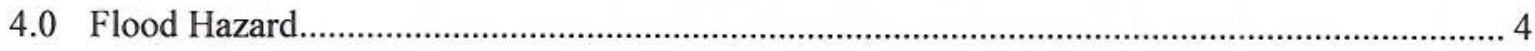

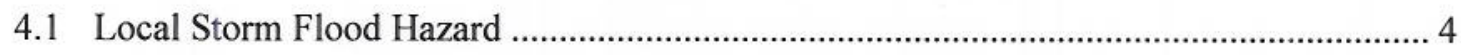

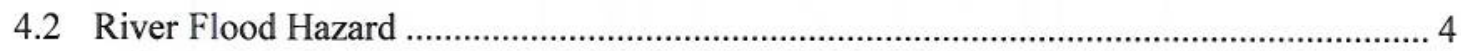

4.3 Flood Hazard Summary ………..................................................................................... 4

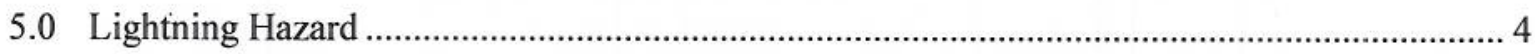

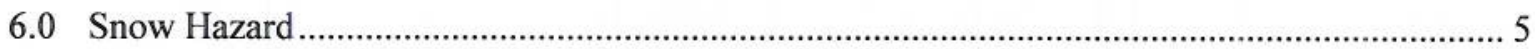

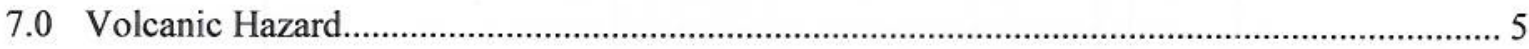

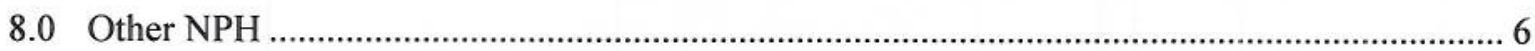

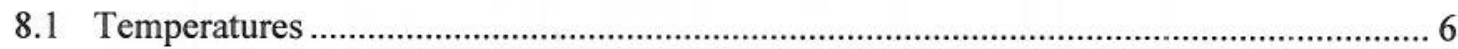

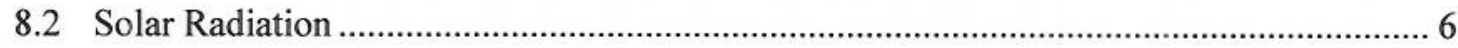

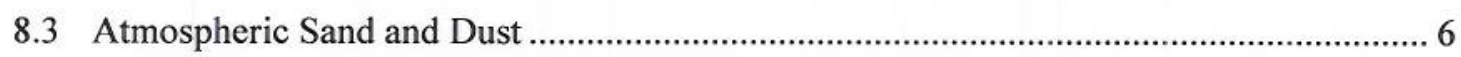

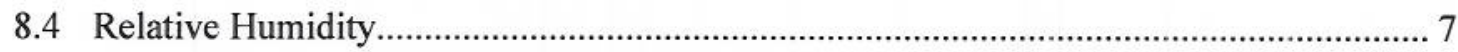

8.5 NPH of DOE G 420.1-2 Appendix C ...................................................................... 7

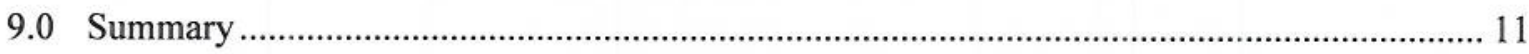

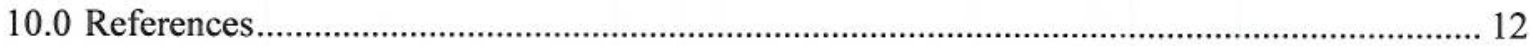




\subsection{Introduction}

\subsection{Purpose}

The purpose of this review is to evaluate the need for revising Natural Phenomena Hazard (NPH) assessments, as required by U.S. Department of Energy (DOE) Order 420.1B, Chapter IV, Natural Phenomena Hazards Mitigation, based on any significant changes in state-of-the-art NPH assessment methodology or site-specific information. This review is an update and expansion to the September 2010 review of PNNL-19751, Review of Natural Phenomena Hazard (NPH) Assessments for the Hanford 200 Areas (Non-Seismic).

\subsection{Scope}

The review scope includes all natural phenomena hazard assessments identified in HNF-SD-GNER-501, Natural Phenomena Hazards, Hanford Site, Washington, which expands the prior review of PNNL-19751 to include the seismic hazard assessment. The geographical scope is expanded from that of PNNL-19751 to include the entire Hanford Site. It was also requested that the DOE G 420.1-2, Guide for the Mitigation of Natural Phenomena Hazards for DOE Nuclear Facilities and Nonnuclear Facilities Appendix C listing of specific natural phenomena hazards be reviewed. Finally, specific recommendations are made for updating assessments and design criteria.

\subsection{Methods}

HNF-SD-GN-ER-501, Natural Phenomena Hazards, Hanford Site, Washington develops NPH design criteria for use in implementing DOE Order 420.1B and the associated design criteria standard DOE-STD-1020-2002, Natural Phenomena Hazards Design and Evaluation Criteria for Department of Energy Facilities. Assessment methodologies and site-specific data, as presented in the current revision of HNF-SD-GN-ER-501, were reviewed for continued relevance compared to approved methodology and more recent site-specific data. It should be noted that DOE-STD-1189-2008, Integration of Safety into the Design Process, effectively revises NPH assessment and design criteria as presented in DOE-STD-1020-2002, specifically with regard to seismic hazard at new facilities.

At this time, DOE Order 420.1 and DOE-STD-1020 are in the process of revision. Recent drafts issued for comment embody substantial changes to the process of NPH assessment and criteria development (compared to current approved requirements), both in framework of application and requirements for analysis and design criteria. Upon approval of these changes, implementation of new requirements may involve more extensive NPH assessment update than is indicated 
below. NPH assessment and design criteria update recommendations below do not consider the potential impact of these draft changes.

Site-specific general climatological data was taken from PNNL-15160, Hanford Site Climatology Summary 2004 with Historical Data. More recent data through August 2010 was taken from the Hanford Meteorological Station website formerly at http://hms.pnl.gov (METDATA). The data reporting website has moved to http://www.hanford.gov/hms; values through July 2011 were taken from there.

\subsection{Seismic Hazard}

The seismic hazard values presented in HNF-SD-GN-ER-501 were based on a probabilistic seismic hazard analysis (PSHA) documented in 1996 as WHC-SD-W236A-TI-002, Probabilistic Seismic Hazard Analysis, DOE Hanford Site, Washington (Geomatrix Report). Methodology for seismic hazard assessment subsequently evolved, starting notably with NUREG/CR-6372, Recommendations for Probabilistic Seismic Hazard Analysis: Guidance on Uncertainty and Use of Experts, which is known informally as the SSHAC guidelines (Senior Seismic Hazard Advisory Committee, 1997). Current PSHA requirements are identified in ANSI/ANS-2.292008, Probabilistic Seismic Hazards Analysis and ANSI/ANS-2.27-2008, Criteria for Investigations of Nuclear Facility Sites for Seismic Hazard Assessments, both now invoked for new facilities by DOE-STD-1189-2008. The existing PSHA is generally considered to have approximately followed the 1997 SSHAC Level 2 process, and as such the methodology may possibly satisfy current requirements for certain limited applications. For the broad range of applications necessary for basing generic Hanford design criteria as developed in HNF-SD-GNER-501 it is likely that a Level 3 PSHA is needed to meet current requirements.

Further, uncertainties in data and ground motion modeling used in the existing PSHA were identified with particular regard to Waste Treatment and Immobilization Plant (WTP) seismic design criteria. These issues may affect other facilities as well, as identified in 2006-RL-HNF0002, New Hanford Site-Specific Seismic Information Affects Existing Safety Basis. For WTP, additional data was collected and model development performed to support WTP design, as documented in PNNL-16652, Site-Specific Velocity and Density Model for the Waste Treatment Plant, Hanford, Washington and PNNL-16653, Updated Site Response Analyses for the Waste Treatment Plant, DOE Hanford Site, Washington. Other facilities and contractors have applied various conservatisms in attempts to bound the noted uncertainties in data and modeling.

Significant changes in data and methodology warrant PSHA update to meet DOE Order 420.1B. This conclusion is also reached and discussed at some length in DOE Memorandum 11-ESD016, July 15, 2011 Hanford Seismic Summit Meeting Notes. The Seismic Summit Notes also identify the history and status of the work plan developed for performing the PSHA update. It is 
recommended that the work plan be confirmed or revised as appropriate and implemented to update seismic hazard assessment, to be followed by design criteria specification to the updated hazard.

As part of the Phase II work scope the development of current WTP design criteria and the evolution of that criteria from the 1996 Geomatrix report to today's design criteria will be described.

\subsection{Wind Hazard}

The current wind hazard assessment in HNF-SD-GN-ER-501 and resulting basic wind speed values were based on site data through 1997, as evaluated in HNF-3329, Hanford Site Peak Gust Wind Speeds. The wind hazard assessment methodology was undergoing change at that time, moving from wind speeds in fastest mile values to peak gust values. The peak gust speeds as assessed in HNF-3329 and reported in HNF-SD-GN-ER-501 Table 3 are consistent with the design methodology up through the 2005 edition of ASCE/SEI 7 (ASCE/SEI 7-05), which remains the current methodology as implemented in the International Building Code, (IBC) 2009 edition. HNF-SD-GN-ER-501 reconciles the design wind speed values with those of DOE's 1998 Interim Advisory on Straight Winds, which was incorporated into DOE-STD-1020-2002.

Site-specific wind speed data since 1997 (PNNL-15160 and METDATA) show monthly peak gust values generally well below the record values evaluated in HNF-3329, with two exceptions: a new record for the month of December was set in 2006 with a peak gust of $74 \mathrm{mph}$ (@ $50 \mathrm{~m}$ ) compared to the previous record of $71 \mathrm{mph}$ in 1955, and a new record for the month of February was set in 2011 with a peak gust of $68 \mathrm{mph}$ compared to the previous record of $65 \mathrm{mph}$ most recently in 1999. This new data is consistent within the probabilistic evaluations of HNF-3329, and revision to the wind hazard assessment on the basis of site data is not indicated at this time.

Tornado winds at the Hanford Site are considered to be of sufficiently low probability that DOESTD 1020-2002 excludes them from further design consideration.

The wind design criteria methodology is changing. The design approach recently published in the ASCE/SEI 7-10 (and in process of incorporation into the 2012 IBC) presents changes to basic wind speeds and their associated recurrence probabilities. It is possible that the current wind hazard assessment at Hanford can be accepted under the provisions in ASCE/SEI 7-10 for estimation of basic wind speeds from regional climatic data, but reconciliation between DOESTD 1020-2002 and ASCE/SEI 7-10 requirements will need to be made. It is recommended that as part of the Phase II work scope that the wind hazard assessment and design criteria be updated to implement the published methodology change in ASCE/SEI 7-10, in anticipation of adoption into the IBC. 


\subsection{Flood Hazard}

\subsection{Local Storm Flood Hazard}

Table 5 of HNF-SD-GN-ER-501 presents extreme precipitation estimates for Hanford based on the National Weather Service predictions in their 1994 Hydrometeorological Report No. 57, Probable Maximum Precipitation - Pacific Northwest States. The National Weather Service still presents this report as current. The most recent probabilistic analysis of Hanford site-specific precipitation data in PNNL-15160 gives precipitation amounts significantly below the extreme estimates of HNF-SD-GN-ER-501.

\subsection{River Flood Hazard}

The Columbia River flood hazard assessment methodology discussed in HNF-SD-GN-ER-501 remains current to DOE-STD 1020-2002 requirements. The river flow data providing the basis for the assessment remains current. A new seismic hazard assessment of the Mid-Columbia dams is underway by the Federal Energy Regulatory Commission; when the resulting report is available it may be pertinent to flood hazard characterization, as dam failure initiated by seismic events was deemed to be the greatest contributor to river flood hazard.

HNF-SD-GN-ER-501 identifies a stream flood risk from the Cold Creek Watershed. PNNL15534, FY 1999 Progress Report on: Potential Groundwater Recharge From the Infiltration of Surface Runoff in Cold and Dry Creeks, discusses this event in more detail, presenting it in a storm flood context and relating it to (and being bounded by) the Probable Maximum Precipitation.

\subsection{Flood Hazard Summary}

Pending new information on the potential for dam failure events, there is no need for revision of flood hazard assessments. Flooding hazard will not be revised as part of the Phase II work scope.

\subsection{Lightning Hazard}

HNF-SD-GN-ER-501 does not itself present any assessment of lightning hazard, but does recommend NFPA 780, Lightning Protection Code (1992 edition), specifically as guidance for lightning protection of the CSB. DOE has since issued guidance for lightning protection via DOE-STD-1066-99, Fire Protection Design Criteria, which invokes NFPA 780 without reference to a specific edition.

It is noted that NFPA 780, Standard for the Installation of Lightning Protection Systems (current edition 2011) includes lightning hazard assessment methodology which has undergone 
substantial changes since the 1992 version. The criteria of HNF-SD-GN-ER-501 with regard to lightning hazard, and any assessments made on that basis, should be considered outdated.

Lightning hazard design criteria will be updated to the current NFPA 780 as part of the Phase II work scope.

\subsection{Snow Hazard}

HNF-SD-GN-ER-501 gives a ground snow load for the Hanford site of $15 \mathrm{lb} / \mathrm{ft}^{2}$, based on the 1995 edition of ASCE/SEI 7 (ASCE/SEI 7-95). Snow load design methodologies have evolved somewhat in recent years, with both ASCE/SEI 7-05 and ASCE/SEI 7-10 showing a ground snow load of $10 \mathrm{lb} / \mathrm{ft}^{2}$ for over most of Hanford, with $15 \mathrm{lb} / \mathrm{ft}^{2}$ at only the southern edge. The current criterion is bounding over the newer requirement, and it is recommended that no specific update is warranted at this time. Snowfall data at Hanford brings no challenge to these values.

\subsection{Volcanic Hazard}

Unlike wind and flood hazard assessment and resulting design methodologies which are reasonably well developed in national codes and standards and have specific DOE implementations (e.g. DOE-STD-1020-2002), volcanic hazard assessment criteria are less well defined. HNF-SD-GN-ER-501 includes ash fall criteria developed from WHC-SD-GN-ER30038, Volcanic Ashfall Loads for the Hanford Site, based on probabilistic volcanic hazard studies of the Cascade Range completed by the U.S. Geological Survey (USGS) dating from 1995.

The USGS has recently released a new ashfall hazard study in Open-File Report 2011-1064, Estimate of Tephra Accumulation Probabilities for the U.S. Department of Energy's Hanford Site, Washington. While this report shows substantially similar predicted thicknesses and probabilities for the ashfall hazard as was previously used in HNF-SD-GN-ER-501, the associated ash density is higher than previously assumed, resulting from the clarification that predicted thicknesses relate to compacted rather than uncompacted ash. This will result in significantly higher structural loading than previously identified.

Design criteria have been requested for airborne concentration of ash. The new USGS report does not provide any direct basis for derivation of airborne concentration; assumptions are necessary to make this development.

An update to volcanic hazard assessment and design criteria at Hanford will be performed as part of Phase II work scope. 


\subsection{Other NPH}

HNF-SD-GN-ER-501 provides additional NPH design criteria on a Hanford site-wide basis as noted in Sections $8.1-8.4$ below. Section 8.5 gives an accounting to all the natural phenomena hazards identified in Appendix C of DOE Guide 420.1-2.

\subsection{Temperatures}

\subsubsection{Ambient Temperatures}

HNF-SD-GN-ER-501 reports a simple range of $115^{\circ} \mathrm{F}$ to $-25^{\circ} \mathrm{F}$ for design temperatures for all performance categories. The range was chosen to envelope historical recorded temperatures at Hanford. A review of recent temperature extremes shows the range is still bounding in this manner, and there is no need for design criteria revision.

\subsubsection{Subsurface Temperatures}

Subsurface temperature design criteria are established in HNF-SD-GN-ER-501based on evaluation of historical hourly subsurface soil temperatures. Review of recent subsurface temperature data available in PNNL-15160 indicates one slightly higher maximum extreme temperature of $156.8^{\circ} \mathrm{F}$ for a depth of $0.5 \mathrm{in}$, but this is still within the design range to $160^{\circ} \mathrm{F}$ at this depth. There is no need for design criteria revision.

\subsection{Solar Radiation}

HNF-SD-GN-ER-501 establishes a maximum solar radiation environment for design of 900 langleys, which is based on the highest recorded measurement of 838 langleys in May 1977. Review of recent data (PNNL-15160 and METDATA) indicates that this previous highest recorded level has not been exceeded, and there is no identified need to revise design criteria.

\subsection{Atmospheric Sand and Dust}

HNF-SD-GN-ER-501 invokes MIL-STD-210C, Climatic Information to Determine Design and Test Requirements for Military Systems and Equipment, as design criteria for systems and components which may be exposed to blowing dust. Available site information gives no cause to doubt the sufficiency of this approach; however the referenced MIL-STD criteria may be dated, having been superseded by the issuing authority. The design criteria for hazard due to atmospheric sand and dust will be addressed as part of the Phase II scope. 


\subsection{Relative Humidity}

HNF-SD-GN-ER-501 conservatively specifies design for relative humidity of near 0 to 100 percent, based on an historical data range of approximately 20 to near 100 percent. Recent data give no reason to change this assessment, and there is no need for design criteria revision.

\subsection{NPH of DOE G 420.1-2 Appendix C}

DOE Guide 420.1-2 Appendix C identifies the following list of natural phenomena hazards to be addressed, with 8.5.1 through 8.5.11 below identified as Primary Natural Phenomena Hazards and the remainder as Secondary Natural Phenomena Hazards. Where HNF-SD-GN-ER-501 includes any discussion of the hazard, the section above which references that discussion is noted. For those hazards currently not discussed, explicitly addressing them requires design criteria update.

\subsubsection{Earthquakes}

Seismic hazards are discussed in Section 2.0 above.

\subsubsection{Volcanic Events}

Volcanic event hazards are discussed in Section 7.0 above.

\subsubsection{Tornadoes}

Tornado hazards are discussed in Section 3.0 above.

\subsubsection{Hurricanes}

Hurricanes are currently not addressed in HNF-SD-GN-ER-501. The Hanford site is geographically far removed from any area considered as susceptible to hurricanes. The basis for not further analyzing the hazard due to hurricanes will be included as a part of the work in Phase II.

\subsubsection{High Winds}

High wind hazards are discussed in Section 3.0 above.

\subsubsection{Floods}

Flood hazards are discussed in Section 4.0 above.

\subsubsection{Excessive rains}

Hazards from excessive rains are discussed as part of flood hazards in Section 4.0 above. 


\subsubsection{Excessive snow}

Snow hazard is discussed in Section 6.0 above.

\subsubsection{Ice cover}

Ice cover is currently not addressed in HNF-SD-GN-ER-501. Ice loading and freezing rain can happen in the Hanford winter climate, and associated design criteria are certainly pertinent to some structures and components. ASCE/SEI 7-10 provides criteria and discussion associated with atmospheric icing hazards. The hazard due to ice cover will be addressed as part of the Phase II scope.

\subsubsection{Lightning}

Lightning hazard is discussed in Section 5.0 above.

\subsubsection{Range fires}

Range fires are currently not addressed in HNF-SD-GN-ER-501. Forest fires are not applicable at Hanford, but range fires present a definite hazard and will be addressed as part of the Phase II work scope.

\subsubsection{Drought}

Drought is currently not addressed in HNF-SD-GN-ER-501. Local drought is normal in the arid Hanford environment. Regional drought that substantially reduces river flow could impact facilities that depend on water availability or the power generated there from. The hazard due to drought will be addressed as part of the Phase II scope.

\subsubsection{Fog}

Fog is currently not addressed in HNF-SD-GN-ER-501. Fog is known to occur seasonally at some locations on the Hanford site, which could bring wetting and reduced visibility hazards. The hazard due to fog will be addressed as part of the Phase II scope.

\subsubsection{Frost}

Frost is currently not addressed in HNF-SD-GN-ER-501. Frost is a common occurrence in Hanford's winter. It is anticipated that any needed discussion of frost could addressed with ice loading. The hazard due to frost will be addressed as part of the Phase II scope.

\subsubsection{High Temperatures}

High temperatures are discussed in Section 8.1 above. 


\subsubsection{Low Temperatures}

Low temperatures are discussed in Section 8.1 above.

\subsubsection{Landslides}

Landslides are currently not addressed in HNF-SD-GN-ER-501. The Hanford topography is generally viewed as having a low potential for landslides (USGS Fact Sheet 2005-3156); however limited areas may have a high to very high potential (e.g. Rattlesnake Mountain). As such, there may be limited specific locations where this potential hazard would need to be examined. The hazard due to landslides will be addressed as part of the Phase II scope.

\subsubsection{Subsidence}

Subsidence is currently not addressed in HNF-SD-GN-ER-501. Land subsidence is a gradual settling or sudden sinking of the Earth's surface owing to subsurface movement of earth materials. The Hanford topography is generally viewed as having the low potential for major causes of subsidence (aquifer system compaction, drainage of organic soils, underground mining, hydrocompaction, natural compaction, sinkholes, and thawing permafrost), USGS Fact Sheet 165-00. There may be specific locations where this potential hazard would need to be examined in the context of groundwater extraction (treatment activities) or previous excavation. The hazard due to subsidence will be addressed as part of the Phase II scope.

\subsubsection{Surface Collapse}

Surface collapse is currently not addressed in HNF-SD-GN-ER-501. Surface collapse is generally viewed as a rapid subsidence. Collapse features tend to be associated with specific rock types (salt, gypsum, limestone and dolomite), having hydrogeologic properties that render them susceptible to the formation of cavities. Hanford soils and stratigraphy are expected to be generally free from a surface collapse hazard (USGS Circular 1182). The hazard due to surface collapse will be addressed as part of the Phase II scope.

\subsubsection{Uplift}

Uplift is currently not addressed in HNF-SD-GN-ER-501. Uplift is the opposite of subsidence. Typically uplift is associated with ground water recharge, volcanism (longer term) and seismic (sudden uplift). The Hanford geology is expected to be generally resistant to uplift hazard. There may be specific locations where this potential hazard 
would need to be examined in the context of groundwater recharge. The hazard due to uplift will be addressed as part of the Phase II scope.

\subsubsection{Storm surges}

Storm surge is currently not addressed in HNF-SD-GN-ER-501. Storm surge is the abnormal rise of water generated by a storm, over and above the predicted astronomical tides (http://www.nhc.noaa.gov/ssurge/index.shtml), typically associated with tropical storms, hurricanes, and typhoons. There is no anticipated hazard to Hanford from storm surges. The basis for not further analyzing the hazard due to storm surges will be included as a part of the work in Phase II.

\subsubsection{Waterspouts}

Waterspouts are currently not addressed in HNF-SD-GN-ER-501. There is no anticipated hazard to Hanford from waterspouts. Tornadic waterspouts result from tornadoes over water, and as identified in Section 3.0 above, tornadoes are sufficiently low probability events as to be excluded from design consideration. Non-tornadic waterspouts are generally limited to tropical and subtropical latitudes. The basis for not further analyzing the hazard due to waterspouts will be included as a part of the work in Phase II. 


\subsection{Summary}

Evolution of seismic hazard assessment methodology and recognition of uncertainty in data used or assumed in the basis for HNF-SD-GN-ER-501 indicate a need to update the PSHA.

Clarifications to ashfall hazard assessment in USGS Open-File Report 2011-1064 result in higher ash loads than previously indicated. It is recommended that the volcanic hazard assessment and design criteria be updated.

Changes to wind hazard assessment and wind design methodology have recently been published in the 2010 edition of ASCE/SEI 7, Minimum Design Loads for Buildings and Other Structures (ASCE/SEI 7-10), which is in the process of being adopted into the next version of the International Building Code (IBC) in 2012. The basic wind speeds and especially the associated probabilities in DOE-STD 1020-2002, as well as HNF-SD-GN-ER-501, will require reconciliation with the new values in the ASCE/SEI 7-10 methodology. It is recommended that this reconciliation be made by the time ASCE/SEI 7-10 is mandated as effective.

Lightning hazard assessment methodology, addressed only by indirect reference in HNF-SDGN-ER-501, has substantially changed. Design criteria update is recommended.

Several specific NPH hazards identified in DOE G 420.1-2 Appendix C have not been explicitly addressed in HNF-SD-GN-ER-501, and revision will be required to do so. 


\subsection{References}

2006-RL-HNF-0002, New Hanford Site-Specific Seismic Information Affects Existing Safety Basis, Fluor Hanford, Inc, Richland, Washington, 2006.

ANSI/ANS-2.27-2008, Criteria for Investigations of Nuclear Facility Sites for Seismic Hazard Assessments, American Nuclear Society, La Grange Park, Illinois, 2008.

ANSI/ANS-2.29-2008, Probabilistic Seismic Hazards Analysis and ANSI/ANS-2.27-2008, Criteria for Investigations of Nuclear Facility Sites for Seismic Hazard Assessments, American Nuclear Society, La Grange Park, Illinois, 2008.

ASCE/SEI 7-05, Minimum Design Loads for Buildings and Other Structures, 2005 Edition, American Society of Civil Engineers \& Structural Engineering Institute, New York, New York, 2005.

ASCE/SEI 7-10, Minimum Design Loads for Buildings and Other Structures, 2010 Edition, American Society of Civil Engineers \& Structural Engineering Institute, New York, New York, 2010.

ASCE/SEI 7-95, Minimum Design Loads for Buildings and Other Structures, 1995 Edition, American Society of Civil Engineers \& Structural Engineering Institute, New York, New York, 1995.

DOE Memorandum 11-ESD-016, P. G. Harrington to File, July 15, 2011 Hanford Seismic Summit Meeting Notes, U.S. Department of Energy Office of River Protection, Richland, Washington, 2011.

DOE G 420.1-2, Guide for the Mitigation of Natural Phenomena Hazards for DOE Nuclear Facilities and Nonnuclear Facilities, U.S. Department of Energy, Washington, D.C, 2000.

DOE Order 420.1B, Chapter IV, Natural Phenomena Hazards Mitigation, U.S. Department of Energy, Washington, D.C, 2005.

DOE-STD-1020-2002, Natural Phenomena Hazards Design and Evaluation Criteria for the Department of Energy Facilities, U.S. Department of Energy, Washington, D.C, 2002.

DOE-STD-1023-95, Natural Phenomena Hazards Assessment Criteria, U.S. Department of Energy, Washington, D.C, Reaffirmed 2002. 
DOE-STD-1066-99, Fire Protection Design Criteria, U.S. Department of Energy, Washington, D.C, 1999.

HNF-3329, J. V. Ramsdell, Hanford Site Peak Gust Wind Speeds, Revision 0, Pacific Northwest National Laboratory for Numatec Hanford Corporation, Richland, Washington, 1998

HNF-SD-GN-ER-501, T. J. Conrads, Natural Phenomena Hazards, Hanford Site, Washington, Revision 1B, Numatec Hanford Company, Richland, Washington, 2002.

Hydrometeorological Report No. 57, E. M. Hansen et al, Probable Maximum PrecipitationPacific Northwest States, National Weather Service, Silver Spring, Maryland, 1994

IBC 2009, International Building Code, 2009 Edition, International Code Council, Inc., Country Club Hills, Illinois, 2009.

METDATA, Hanford Meteorological Data Monthly Summaries January 2005 through August 2010, generated from http://hms.pnl.gov/products/, September 15, 2010.

MIL-STD-210C, Climatic Information to Determine Design and Test Requirements for Military System and Equipment, U.S. Department of Defense, Washington, D.C, 1987.

NFPA 780, Lightning Protection Code, National Fire Protection Association, Quincy, Massachusetts, 1992.

NFPA 780, Standard for the Installation of Lightning Protection Systems, National Fire Protection Association, Quincy, Massachusetts, 2011 (current version).

NUREG/CR-6372, Recommendations for Probabilistic Seismic Hazard Analysis: Guidance on Uncertainty and Use of Experts, U.S. Nuclear Regulatory Commission, Washington, D.C, 1997.

PNNL-15160, D. J. Hoitink and K.W. Burk, et al, Hanford Site Climatology Summary 2004 with Historical Data, Pacific Northwest National Laboratory, Richland Washington, 2005.

PNNL-15534, M. S. Wigmosta and G. R. Guensch, FY 1999 Progress Report on: Potential Groundwater Recharge From the Infiltration of Surface Runoff in Cold and Dry Creeks, Pacific Northwest National Laboratory, Richland Washington, 2005.

PNNL-16652, A. C. Rohay and T. M. Brouns, Site-Specific Velocity and Density Model for the Waste Treatment Plant, Hanford, Washington, Pacific Northwest National Laboratory, Richland Washington, 2007. 
PNNL-16653, R. R. Youngs, Updated Site Response Analyses for the Waste Treatment Plant, DOE Hanford Site, Washington, Pacific Northwest National Laboratory, Richland Washington, 2007.

PNNL-19751, R. L. Snow, S. B. Ross and R. S. Sullivan, Review of Natural Phenomena Hazard (NPH) Assessments for the Hanford 200 Areas (Non-Seismic), Pacific Northwest National Laboratory, Richland Washington, 2010.

UCRL-21069, M.W. McCann Jr. and A.C. Boissonnade, Probabilistic Flood Hazard Assessment for the N-Reactor, Hanford, Washington, Lawrence Livermore National Laboratory, Livermore, California, 1998.

USGS Circular 1182, D. Galloway, D.R. Jones and S.E. Ingebritsen, Land Subsidence in the United States, U.S. Geological Survey, Reston, Virginia, 1999.

USGS Fact Sheet 165-00, Land Subsidence in the United States, U.S. Geological Survey, Reston, Virginia, 2000.

USGS Fact Sheet 2005-3156, Landslide Hazards- A National Threat, U.S. Geological Survey, Reston, Virginia, 2005.

USGS Open-File Report 2011-1064, R. P. Hoblitt and W. E. Scott, Estimate of Tephra Accumulation Probabilities for U.S. Department of Energy's Hanford Site, Washington, U. S. Geological Survey, Reston, Virginia, 2011.

WHC-SD-GN-ER-30038, Volcanic Ashfall Loads for the Hanford Site, Rev. 0, Westinghouse Hanford Company, Richland, Washington, 1996.

WHC-SD-W236A-TI-002, Probabilistic Seismic Hazard Analysis, DOE Hanford Site, Washington, Rev. 1A, Geomatrix for Fluor Daniel Hanford, Richland, Washington, 1996. 


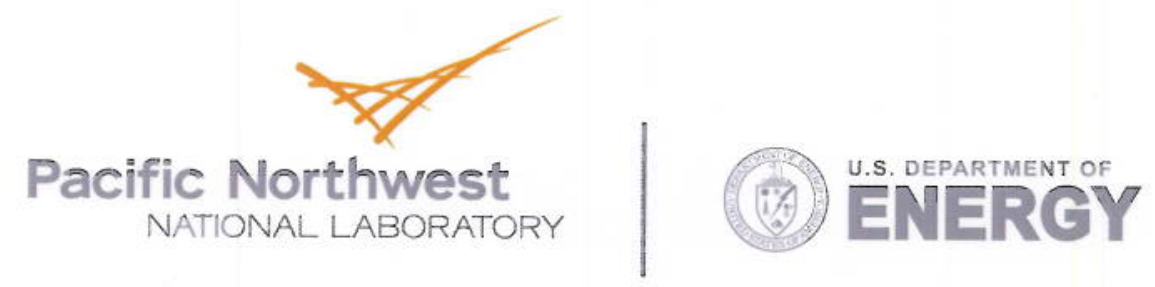

902 Battelle Boulevard

P.O. Box 999

Richland, WA 99352

1-888-375-PNNL (7665)

www.pnl.gov 